\title{
THE EFFECTS OF RICE HUSK ASH AND DOLOMITE ON SOYBEAN YIELD AT LATOSOL SOIL
}

\author{
Aditya Perdanatika*, Suntoro, and Pardjanto \\ Agronomy Department, Graduate School, Universitas Sebelas Maret \\ JI. Ir Sutami 36A, Surakarta, Jawa Tengah \\ Submitted: 2017-08-24 Accepted: 2018-04-07
}

\begin{abstract}
The aim of this research is to evaluate the effects ofrice husk ash and dolomite application on soybean yield at latosol soil. This research was conducted at a plastic house from September to December 2016. This research employed Factorial Randomized Complete Design with two factors and three replications. The first factor is the dosage of rice husk ash, consisted of four levels (0 (control), 3.75 ton ha- ${ }^{-1}, 7.5$ ton ha- ${ }^{-1}$ and 15 ton ha-1), and the second factor is the dosage of dolomite consisted of three levels (0 (control), 250 and $500 \mathrm{~kg} \mathrm{ha}^{-1}$, respectively). The results found that the application of 15 tons ha ${ }^{-1}$ rice husk significantly affected the number of full pods and total pods, but did not affect the number of the empty pods. The application of 3.75 tons ha ${ }^{-1}$ husk ash increased the seed weight and weight of 20 dry seeds. It was also found that the higher the rice husk ash dose applied, the more root nodules produced.
\end{abstract}

Keywords: husk ash, dolomite, latosol soil, soybean yield, nutrients in soil

How to Cite: Perdanatika, A., Suntoro, Mujiyo (2018). The Effect of Rice Husk Ash and Dolomite on Soybean Yield at Latosol Soil. Sains Tanah Journal of Soil Science and Agroclimatology, 15 (1): 29-34 (doi: 10.15608/stjssa.v15i1.21620)

Permalink/DOI: http://dx.doi.org/10.15608/stjssa.v15i1.21620

\section{INTRODUCTION}

Soybean (Glycine max (L.) Merrill) is a commercial crop in more than 35 countries and have been used in food industry worldwide. Soybean is oftenly used as a substitute component of meat protein due to its high protein content. Soya protein is the main source of amino acids for human nutrition (EIShemy, 2011).

Soybean is the main source of highquality protein, which is important for human health., and thus urgent for countries which low consumption of animal protein. It contains 30 to $50 \%$ protein which closes to the milk protein from cow.

* Corresponding Author :

Email :aditya.perdanatika@yahoo.com
The fat content is approx. 15 to $20 \%$, with vitamin A, B, C and D. Improving the quality of soybean seed may become the key to increase nutrition for humans (Bellaloui, et al., 2010).

Serious efforts are necessary to improve food security at the national level, particularly to increase the soybean production. Planning a long-term program as the efforts must be in target. The main objective is to increase the domestic production gradually to meet the demand, and thus the import can be reduced (Adisarwanto, 2008).

Latosol is the soil type that can be found in many tropical or sub-tropical areas. It is widely used for cultivation, subsistence farming, and intensive plantations such as sugarcane, pineapple, banana, and coffee. Latosols need fertilizer as amendment, to 
improve agricultural production. Latosol is generally nutrient poor soil, reacts slightly to slightly acidic $(\mathrm{pH}<5)$, and contains low levels of organic matter, which soil spreads worldwide. More than $40 \%$ of the world's farm lands are acidic, with low phosphorus (P) availability, which is considered as a major constraint to crop growth, especially on freshly cultivated soils (Conde, Chen, Chen, \& Liao, 2014). Phosphorus is an important macronutrient for crop growth the, and abundant in soil. Nevertheless, the available $P$ for crop is frequently limited, especially in acid soils because $P$ is easily bond by other soil components and thus unavailable for crops. Therefore, the low $\mathrm{P}$ availability is a major constraint to crop production on acid soils (Aref, 2011).

Rice husk waste is a fibrous material containing cellulose, lignin, and hemicellulose. It produces enormous ash and silica (87-97\%), contains $1 \%$ Nitrogen and $2 \%$ potassium. The roles of potassium in ash husk are strengthen the plant, manage the respiratory system, assist the transpiration of enzyme work and maintain the osmotic potential. Silicon can be the trigger of some Gramineae plants growth, particularly at the optimal concentrations or doses (Martanto, 2001).

Calcification of acidic soil influences soil $\mathrm{pH}$ and nutrient conditions, and also reduces toxic effects which usually emerge in acid soil. The benefits of soil calcification are increase soil $\mathrm{pH}$, soil $\mathrm{Ca}, \mathrm{Mg}, \mathrm{P}$ and $\mathrm{Mo}$ contents, reduce $\mathrm{Fe}, \mathrm{Mn}$, and $\mathrm{Al}$ poisoning. Soil calcification also improves plants growth and root nodules (O'hara, Boonkerd, \& Dilworth, 1988).

Dolomite $\left(\mathrm{CaMg} \quad\left(\mathrm{CO}_{3}\right)_{2}\right)$ provides calcium, which play a significant role in the apical growth and flower formation, and thus increases soybean production has a significant role. It is important in cell division, cell permeability regulation and water regulation in cells, seed germination, and development of stamen and Rhizobium root nodules.
Magnesium plays a role in the nitrogen metabolism by plant, and thus the higher the magnesium absorption, the higher protein level plant root or top part. Magnesium contained in the dolomite is a macro mineral that acts as an activator of various enzymes related to the metabolism of proteins and carbohydrates (Pramita, Periadnadi, \& Nurmiati, 2015).

\section{MATERIALS AND METHODS}

This research was conducted in Bener, Tengaran District, Semarang Regency, Indonesia from September to December 2016, in a plastic house. The research design was Factorial Randomized Block Design (RBD) with two factors and three replications. The first factor was rice husk ash dose, consisted of 4 dose levels, i.e.: 0 (as control), 3.75, 7.5 and 15 tons $\mathrm{ha}^{-1}$, respectively. The second factor was dolomite dose, consisted of 3 levels: 0 grams (as control), 250 and $500 \mathrm{~kg} \mathrm{ha}^{-1}$. Parameters observed were the number of full pods, number of empty pods, total pods, seed weight, the weight of 20 dry seeds, and the number of root nodules which are sampled from 30 plants per treatment group.

\section{RESULTS AND DISCUSSION}

\section{Number of Full and Empty Pods}

Statistical analysis (Analysis of Variance) revealed thatrice husk ash dose significantly affected full pods number per plant (Figure 1). Treatment followed by the same letter in the same column indicates no significant differences in Duncan's multiple range test with the significance of $5 \%$. Figure 1 indicates that nutrient availability influenced plant growth, since rice husk ash doses which are intended as additional nutrients resulted in significantly different numbers of full and empty pods per plant. The availability of potassium can stimulate the photosynthesis process, increase the distribution of photosynthate and eventually encourage 
Perdanatika et al. / SAINS TANAH - Journal of Soil Science and Agroclimatology, 15(1), 2018, 31

growth and crop yield (Pettigrew, 2008). Seeds are the living link between the parent and the offspring plant, which are the primary means of proliferation (Gardner, 1991).

Figure 1 (a) shows rice husk ash dose up to 15 tons ha ${ }^{-1}$ significantly increased the number of full pods per plant. That is because potassium and silica contained in rice husk ash play roles in plants metabolism and growth (Martanto, 2001). According to Gardner, Pearce, \& Mitchell (2002), photosynthate is transported to plants cells so they can grow and develop. The distribution of photosynthate is strongly influenced by plants circumstances and properties, which affects the formation of pods. Isbandi, Wartoyo, \&

(a)

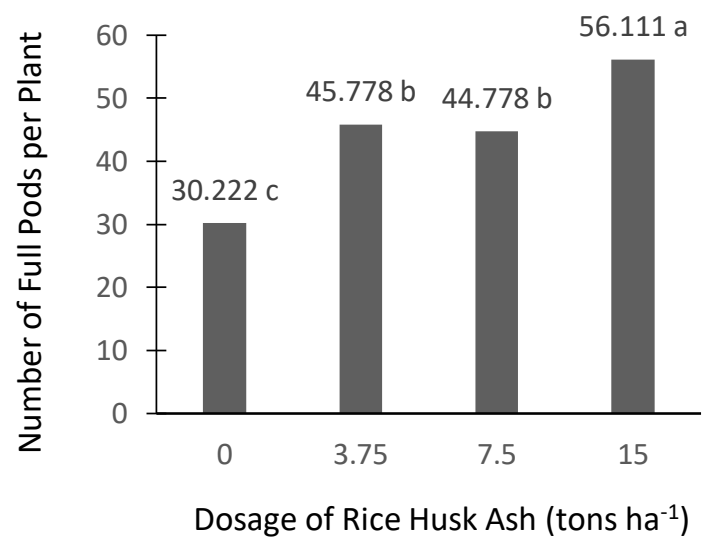

Suharto (2001) reported that the presence of flower and fruit depends on the absorption of nutrients by plants. The more nutrients were absorbed, the more pods produced, and vice versa.

\section{Total Pods Number}

Figure 2 shows rice husk ash dose significantly affected the total pods number. Figure 2 may indicate total pods number reduced due to the lack of water or nutrients and high temperature. Seed production is determined by dry weight accumulation velocity and duration in the seed. Only $40 \%$ of the soybean flowers will become pods.

(b)

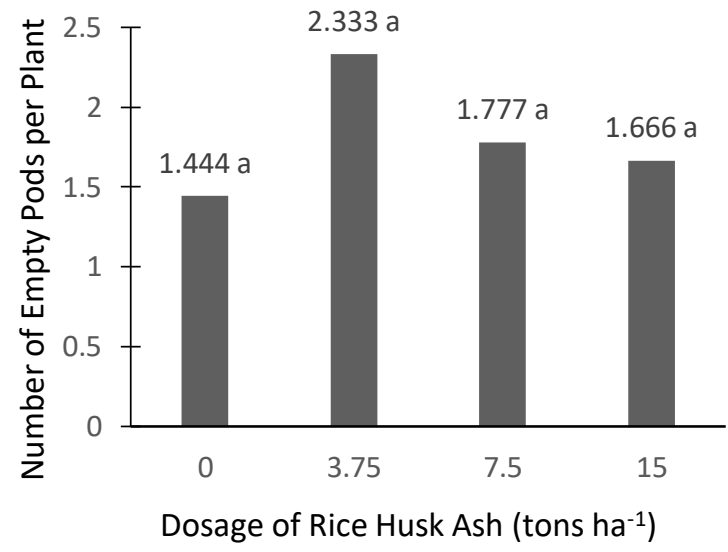

Figure 1. Rice husk ash dose on number of full (a) and empty pods (b)

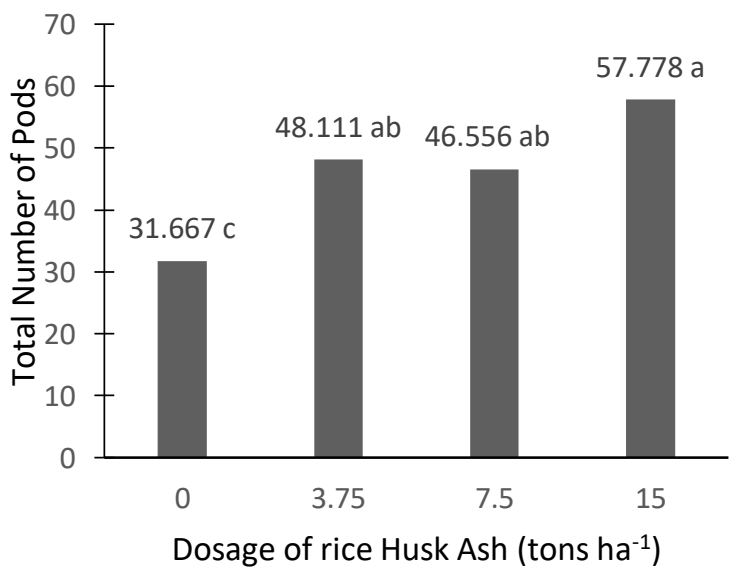

Figure 2. Rice husk ash dose on total pods number 
Calcium (Ca) is required by legume started from the beginning of fruit formation until it becomes fully grown pods. If the growth is good, the pods can produce good seeds (Kabir, Yeasmin, Islam, \& Sarkar, 2013). Related to the dolomite contribution on pod formation, Suntoro (2002) said that dolomite increased calsium and magnesium contents in soil, whereas magnesium is a required ingredient in chlorophyll synthesis, which will determine the ongoing process of photosynthesis. The optimal process of photosynthesis is very important for plant growth, especially in the pods formation and filling phase, as will also determine the yield. Consequently, the application of organic material combined with dolomite significantly promoted the pods formation.

\section{Seeds Weight}

The weight of 20 dry seeds was observed as an arbitrary number to keep the calculations simple, due to soybean cannot produce 100 seeds per plant. Figure 3 shows that rice husk ash dose significantly effected the seeds weight per plant, with. the highest seeds weight was found in 15 tons ha ${ }^{-1}$ of rice husk ash dose treatment. However, amending soil with rice husk ash up to 3.75 tons ha- ${ }^{-1}$ has been able to increase the seeds weight per plant.

(a)

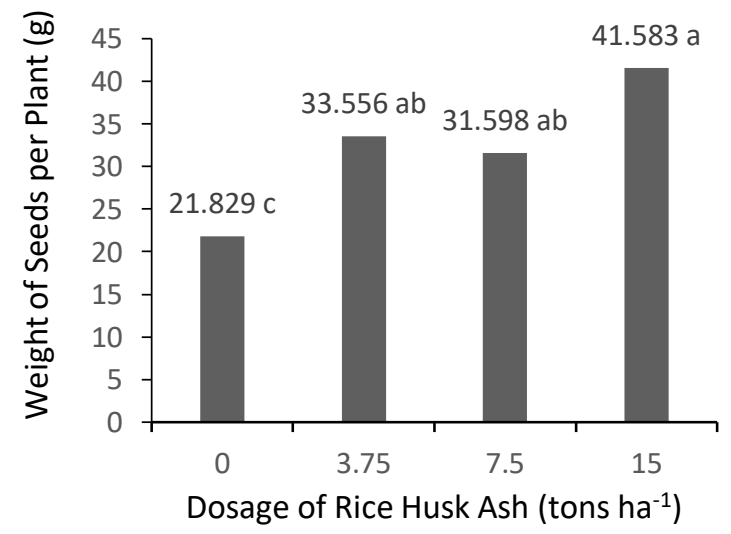

Potassium is one of the essential nutrients needed in large quantities after nitrogen and phosphate. Potassium plays an important role in plant growth such as regulating the availability of other nutrients, stimulating photosynthesis, helping in the process of photosynthesis, becoming a catalyst in protein synthesis, spurring crop growth, and improving crop quality (Read, Reddy, \& Jenkins, 2006). Thus potassium from rice husk ash has an effect on seed formation.

The balance between carbohydrates in the leaves and nitrogen in the roots is necessary to obtain a good dry weight production. Drought or nutrient deficiency can reduce the speed and duration of seed formation, but well-balanced NPK fertilizer can increase the seed weight of soybean (Hanum, 2013).

Initial vegetative growth of particular seed allows plants to absorb more photosynthetic energy as the size increases, as well as absorbing adequate water and nutrient to support the leaf growth. During the initial flowering stage, the number of leaves is affected by temperature and photo period. Seed is the dominant part to store the assimilation results, and thus the seed weight of seasonal crops increases immediately after seed initiation (Gardner, 1991).

(b)

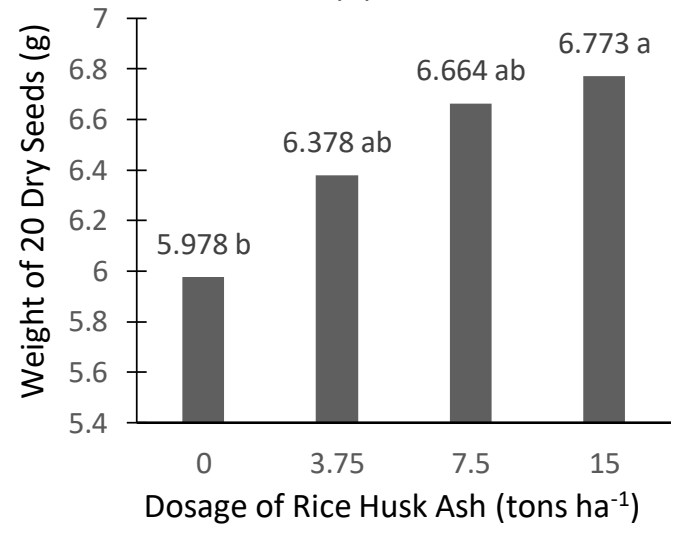

Figure 3. Rice husk ash dose on seeds weight per plant (a) and weight of 20 dry seeds (b). 


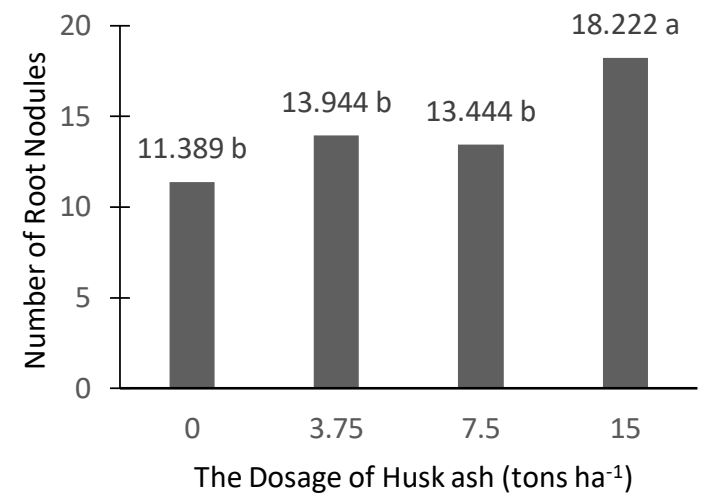

Figure 4. Rice husk ash dose (tons ha-1) on number of root nodules

The air temperature fluctuations also greatly influence soybean growth. The growth of soybean in the dry season under air temperature ranges from 20 to $30{ }^{\circ} \mathrm{C}$ is more optimal compared to that in the rainy season, with better seed quality (Adisarwanto, 2008)

\section{Number of Root Nodules}

Figure 4 shows the number of root nodules increased (18.222) in 15 tons ha ${ }^{-1}$ rice husk ash application, that that of control (11.389).

Phosphorus is very useful element in stimulating the new roots growth of the seedlings. It is also the raw material for proteins formation and promotes the assimilation and respiratory process. Furthermore, phosphorus is also beneficial in accelerating the crop generative phase, as well as ripening seeds and fruits (Schoninger, Gatiboni, \& Ernani, 2012).

Phosphorus $(P)$ plays an important role in the formation of root nodules (Kabir, Yeasmin, Islam, \& Sarkar, 2013). The growth of root nodules highly depends on environmental factors such as nutrients, temperature, ground water table, and genetical factor. Phosphorus contained in rice husk ash was found to promote the seed germination acceleration, and. In general, phosphorus is important for crops to strengthen seedlings growth becomes fully grown crops, stimulates the roots growth, accelerate flowering, promote fruits, seeds and grains ripening, , as well as to increase grain production (Soepardi, 2003).

\section{CONCLUSIONS}

1. Amending soil with 15 tons ha ${ }^{-1}$ rice husk ash increased the number of full pods and total number of pods but did not affect on the number of empty pods.

2. 3.75 tons $\mathrm{ha}^{-1}$ rice husk ash has been able to increased seeds weight per plant and weight per 20 dry seeds.

3. The higher the dose of rice husk ash, the more root nodules produced.

\section{REFERENCES}

Adisarwanto, T. (2008). Budidaya Kedelai Tropika. Jakarta: Penebar Swadaya.

Aref, F. (2011). Influence of Zinc and Boron Nutrition on Copper, Manganese and Iron Concentrations in Maize Leaf. Aust. Journal. Basic Appl. Sci., 5, 52-62.

Bellaloui, N., Bruns, H. A., Gillen, A. M., Abbas, H. K., Zablotowicz, R. M., Mengistu, A., \& Paris, R. L. (2010). Soybean Seed Protein, Oil, Fatty Acids, and Mineral Composition as Influenced by SoybeanCorn Rotation. Agricultural Sciences, 1(3), 102-109. doi:10.4236/as.2010.13013

Conde, L. D., Chen, Z., Chen, H., \& Liao, H. (2014). Effects of Phosphorus Availability on Plant Growth and Soil Nutrient Status in the Rice/Soybean Rotation System on Newly Cultivated Acidic Soils. American Journal of Agriculture and Forestry, 2(6), 309-316. doi:10.11648/j.ajaf.20140206.23

El-Shemy, H. (2011). Soybean and Nutrition. (H. El-Shemy, Ed.) Rijeka: InTech. doi:10.5772/1008

Gardner, F. P. (1991). Fisiologi Tanaman Budidaya. (H. Susilo, Trans.) Jakarta, Indonesia: Universitas Indonesia.

Gardner, F. P., Pearce, R. B., \& Mitchell, R. L. (2002). Fisiologi Tanaman Budidaya. (H. Susilo, Trans.) Jakarta: Universitas Indonesia. 
Perdanatika et al. / SAINS TANAH - Journal of Soil Science and Agroclimatology, 15(1), 2018, 34

Hanum, C. (2013). Pertumbuhan, Hasil, dan Mutu Biji Kedelai dengan Pemberian Pupuk Organik dan Fosfor. J. Agron, 41(3), 209-214.

Isbandi, D., Wartoyo, \& Suharto. (2001). Fisiologi Pertumbuhan dan Perkembangan Tanaman I dan II. Surakarta: Fakultas Pertanian, Universitas Sebelas Maret.

Kabir, R., Yeasmin, S., Islam, A. K., \& Sarkar, M. A. (2013). Effect of Phosphorus, Calcium and Boron on the Growth and Yield of Groundnut (Arachis hypogea L.). International Journal of Bio-Science and Bio-Technology, 5(3), 51-60. doi:10.3923/ijss.2017.18.24

Martanto. (2001). Pengaruh Abu Sekam Terhadap Pertumbuhan Tanaman Dan Intensitas Penyakit Layu Fusarium Pada Tomat. Jurnal Irian Jaya Agro, 8, 37-40.

O'hara, G. W., Boonkerd, N., \& Dilworth, M. J. (1988). Mineral Constraints to Nitrogen Fixation. Plant and Soil, 108(1), 93-110. doi:10.1007/BF02370104

Pettigrew, W. T. (2008). Potassium Influences on Yield and Quality Production for Maize, Wheat, Soybean and Cotton.
Physiologia Plantarum, 133(4), 670-681. doi:10.1111/j.1399-3054.2008.01073.x

Pramita, I., Periadnadi, \& Nurmiati. (2015). Pengaruh Kapur dan Dolomit Terhadap Pertumbuhan Miselium dan Produksi Jamur Kuping Hitam (Aurularia polythrica (Mont.) Sacc.). Online Journal of Natural Science, 4(3), 329-337.

Read, J. J., Reddy, K. R., \& Jenkins, J. N. (2006). Yield and Fiber Quality of Upland Cotton as Influenced. Europen Journal of Agronomy, 24, 282-290. doi:10.1016/j.eja.2005.10.004

Schoninger, E. L., Gatiboni, L. C., \& Ernani, P. R. (2012). Rhizosphere pH and Phosphorous Forms in an Oxisol Cultivated with Soybean, Brachiaria. Scientia Agricola, 69(4), 259 - 264.

Soepardi, G. (2003). Sifat dan Ciri Tanah. Bogor: Departemen Ilmu Tanah Fakultas Pertanian Institut Pertanian Bogor.

Suntoro. (2002). Pengaruh Penambahan Bahan Organik, Dolomit dan $\mathrm{KCl}$ terhadap Kadar Klorofil dan Dampaknya pada Hasil Kacang Tanah (Arachis hypogeae L.). BiOSMART, 4(2), 36-40. 